\title{
Kapasitas Kader dalam Penyuluhan Keluarga Berencana di Kota Palembang, Provinsi Sumatera Selatan
}

\section{Family Planning Volunteers Capacity in Extension in Palembang City, South Sumatera Province}

\author{
Shanti Devi ${ }^{1}$, Anna Fatchiya ${ }^{2}$, Djoko Susanto ${ }^{2}$ \\ ${ }^{1}$ Alumni Program Studi Ilmu Penyuluhan Pembangunan, Sekolah Pascasarjana, Institut Pertanian Bogor \\ ${ }^{2}$ Departemen Sains Komunikasi dan Pengembangan Masyarakat, Fakultas Ekologi Manusia, \\ Institut Pertanian Bogor, Bogor
}

\begin{abstract}
Through Family Planning Program, efforts are made to regulate the birth of children, birth spacing, and ideal ages for childbirth. In addition, family planning also regulates pregnancy and carries out socialization, protection and assistance in accordance with the right of reproduction to create quality family. The aims of this study were (1) to identify the capacity level of family planning volunteers in extension in Palembang city, and (2) to analize the factors related to the capacity of family planning volunteers in extension in Palembang city. The study was conducted from August to September 2015 in Palembang city. The study population totalled 4020 family planning volunteers in Palembang city, and the data collection was conducted toward 100 family planning volunteers. The sampling technique was based on area random sampling. The research data included primary data and secondary data. Furthermore, the data were analyzed quantitatively, and a Spearman Rank correlation test was used to test the hypotheses that had been formulated. The research results showed that (1) the capacity of family planning volunteers was of low level, (2) the capacity was closely related to the experience, training, interaction with extension officers, and information support.
\end{abstract}

Keywords: Family planning volunteers, capacity, extension, family planning

\section{Abstrak}

Melalui Keluarga Berencana diupayakan mengatur kelahiran anak, jarak dan usia ideal melahirkan, mengatur kehamilan, melakukan promosi, perlindungan dan bantuan sesuai dengan hak reproduksi untuk mewujudkan keluarga yang berkualitas. Tujuan penelitian adalah: (1) Mengidentifikasi tingkat kapasitas kader Keluarga Berencana dalam kegiatan penyuluhan Keluarga Berencana di Kota Palembang. (2) Menganalisis faktor-faktor yang berhubungan dengan kapasitas kader Keluarga Berencana dalam kegiatan penyuluhan Keluarga Berencana di kota Palembang. Penelitian dilakukan pada bulan Agustus sampai September 2015 di Kota Palembang. Populasi penelitian adalah 4020 kader Keluarga Berencana di Kota Palembang dan pengumpulan data dilakukan kepada 100 kader Keluarga Berencana. Teknik pengambilan sampel berdasarkan area random sampling. Data penelitian meliputi data primer dan data sekunder. Selanjutnya data dianalisis secara kuantitatif serta untuk menguji hipotesis yang telah dirumuskan digunakan uji korelasi Rank Spearman. Hasil penelitian menunjukkan bahwa tingkat kapasitas kader Keluarga Berencana di Kota Palembang termasuk kategori rendah. Faktor yang penting diperhatikan untuk mengembangkan kapasitas kader Keluarga Berencana adalah: pengalaman, pelatihan yang diikuti, dukungan penyuluh, dan dukungan informasi.

Kata kunci: Kader Keluarga Berencana, kapasitas, penyuluhan, Keluarga Berencana

\section{Pendahuluan}

Indonesia merupakan negara dengan jumlah penduduk terbanyak ke-4 di dunia. Berdasarkan data Badan Pusat Statistik (BPS) tahun 2013, jumlah penduduk Indonesia adalah 248,8 juta jiwa. Masalah kependudukan ini diikuti oleh masalah kemiskinan dan pengangguran. Data BPS (2013) menunjukkan bahwa jumlah penduduk miskin di Indonesia mencapai 28,55 juta orang atau $11,47 \%$ dari total penduduk Indonesia; sedangkan jumlah pengangguran terbuka sebanyak $6,25 \%$ atau 15,55 juta orang (www.bps.go.id).

Mengatasi berbagai masalah kependudukan diperlukan langkah nyata, salah satu program yang dipandang penting adalah Keluarga Berencana (KB). Melalui KB diupayakan mengatur kelahiran anak, jarak dan usia ideal melahirkan, mengatur kehamilan, melakukan promosi, perlindungan dan bantuan sesuai dengan hak reproduksi untuk mewujudkan keluarga yang berkualitas UU nomor 52 tahun 2009). Program KB tidak "sekedar" bertujuan mengendalikan penduduk (birthcontrol), melainkan diarahkan hingga sampai pada terwujudnya keluarga berkualitas.

Mewujudkan keluarga berkualitas dalam lingkungan yang sehat, perlu diprioritaskan karena keluarga merupakan unit sosial ekonomi terkecil dalam masyarakat yang menjadi landasan dasar suatu masyarakat. Keluarga juga mempunyai sejumlah fungsi 
strategis yang tidak dapat digantikan oleh lembaga manapun. Terbentuknya keluarga berkualitas akan melahirkan masyarakat dan bangsa yang berkualitas.

Melalui program KB, perempuan bisa mengatur kehamilannya dan angka kematian ibu hamil dapat ditekan. Program KB juga menurunkan konsumsi, biaya kesehatan reproduksi serta biaya pendidikan. Ibu berkesempatan mengembangkan potensi dirinya, serta anak yang dilahirkan menjadi lebih sehat dan cerdas karena perhatian dan nutrisi yang cukup (www. bkkbn.go.id). Sejalan dengan hal tersebut, program KB mendukung pembangunan Sumber Daya Manusia (SDM); karena pembangunan kualitas sumberdaya manusia akan sulit terlaksana jika jumlah penduduk tidak terkendali.

Seiring dengan diterapkannya otonomi daerah dengan konsep desentralisasi, justru menyebabkan "terbengkalainya" program KB. Keadaan ini menjadikan program KB tidak tersosialisasi dengan baik kepada masyarakat. Penelitian Puspita (2011) menyebutkan bahwa menurunnya kuantitas dan kualitas program KB berakibat rendahnya pemahaman masyarakat tentang pentingnya program $\mathrm{KB}$. Hal tersebut diperkuat penelitian Utsman (2002) dan Amanah et al., (2009) yang menemukan rendahnya tingkat pengetahuan pasangan usia subur tentang $\mathrm{KB}$ dan Kesehatan Reproduksi (KR). Penelitian Harun (2014) menyatakan bahwa rendahnya pengetahuan masyarakat tentang program $\mathrm{KB}$ menyebabkan rendahnya peserta aktif $\mathrm{KB}$.

Puspita (2011) menyimpulkan bahwa rendahnya pemahaman dan keikutsertaan masyarakat dalam program KB berdampak pada meningkatnya pertumbuhan penduduk dengan pesat. Berdasarkan data BPS tahun 2013, laju pertumbuhan penduduk Indonesia adalah 1,49\% pertahun, artinya setiap tahun terjadi pertambahan penduduk 3-4 juta orang. Data BPS juga menunjukkan bahwa rata-rata jumlah anak yang dilahirkan dari seorang perempuan usia produktif (Total Fertility Rate) adalah 2,6 masih jauh diatas dari target 2,11 (www.bps.go.id).

Pelaksanaan program KB membutuhkan keseriusan dalam keterlibatan semua pihak, termasuk petugas lapangan $\mathrm{KB}$ sebagai pihak yang berhubungan langsung dengan masyarakat. Hal ini berkaitan dengan kemampuan petugas pelaksana penyuluhan. Pelaksana penyuluhan KB adalah para Penyuluh KB (PKB) dan kader KB. Berdasarkan data Badan Kependudukan dan Keluarga Berencana Nasional (BKKBN), jumlah PKB pada tahun 2014 adalah 22.481 orang. Jumlah ini baru memenuhi 56,2\% dari jumlah PKB ideal yang dibutuhkan yaitu setiap desa mempunyai dua PKB (www.bkkbn.go.id). Sehubungan ketidakcukupan jumlah PKB, maka dalam menjalankan tugas, dibantu oleh kader KB yang merupakan penduduk setempat.

Kenyataannya di lapangan, kader KB yang lebih banyak berperan dalam kegiatan penyuluhan KB; karena jumlahnya yang lebih banyak dan kedekatan tempat tinggal menjadikan lebih sering berinteraksi dengan masyarakat. Kader KB sebagai pelaksana penyuluh KB di lapangan, disamping mengatasi masalah ketidakcukupan jumlah PKB, juga sejalan dengan pendekatan community-basedservice delivery, yaitu dalam rangka mendekatkan pelayanan KB kepada masyarakat (Herartri, 2008). Pendekatan berbasis komunitas (community-based) tersebut, program KB kemudian menjadikan partisipasi komunitas (community participation) atau peran-serta masyarakat sebagai kebijakan utama, yaitu diantaranya merekrut kader KB sebagai pelaksana penyuluh KB di lapangan.

Untuk itu diperlukan upaya peningkatan kapasitas kader KB, agar kegiatan penyuluhan KB lebih optimal dan efektif. Upaya-upaya untuk mengembangkan kapasitas kader KB dapat dilakukan terlebih dahulu dengan mengetahui sejauhmana tingkat kapasitas yang telah dimiliki oleh kader KB dan mengkaji faktor-faktor apa saja yang berhubungan dengan kapasitas kader KB.

Palembang merupakan kota dengan kepadatan penduduk yang tinggi dan laju pertumbuhan penduduk di atas rata-rata nasional. Berdasarkan data BPS (2013) laju pertumbuhan penduduk Indonesia mencapai $1,49 \%$, jauh dari angka ideal yang semestinya di bawah $1 \%$. Laju pertumbuhan penduduk kota Palembang, di atas rata-rata nasional, yaitu 1,76\%. Dibandingkan dengan kota dan kabupaten lain di Provinsi Sumatera Selatan, Palembang merupakan kota dengan kepadatan penduduk paling tinggi. Upaya mengurangi laju pertumbuhan penduduk dapat dilakukan dengan mengendalikan jumlah kelahiran dan penundaan usia kawin, sehingga diperlukan peran kader KB.

Berdasarkan uraian di atas, dirumuskan permasalahan penelitian sebagai berikut: (1) Bagaimana tingkat kapasitas kader KB dalam kegiatan penyuluhan KB di kota Palembang? (2) Faktor-faktor apa saja yang berhubungan dengan kapasitas kader KB dalam kegiatan penyuluhan KB di kota Palembang?

Berdasarkan masalah penelitian yang telah dirumuskan, maka tujuan penelitian adalah: (1) Mengidentifikasi tingkat kapasitas kader $\mathrm{KB}$ dalam 
kegiatan penyuluhan KB di Kota Palembang. (2) Menganalisis faktor-faktor yang berhubungan dengan kapasitas kader KB dalam kegiatan penyuluhan KB di Kota Palembang.

\section{Metode Penelitian}

Penelitian dilakukan pada bulan Agustus sampai September 2015 di Kota Palembang Provinsi Sumatera Selatan. Berdasarkan tujuan penelitian yang hendak dicapai, maka jenis penelitian yang digunakan adalah explanatory research dengan metode survey.

Populasi penelitian adalah 4.020 kader KB dan diambil sampel sebanyak 100 kader KB. Mengingat keterbatasan waktu, tenaga, dan biaya, maka penarikan sampel dilakukan pada lima kecamatan (area random sampling), dari 16 kecamatan di Kota Palembang. Pemilihan lima kecamatan mewakili kawasan utara, selatan, timur, barat, dan tengah Kota Palembang. Penentuan kecamatan terpilih dilakukan secara acak dari beberapa kecamatan pada kawasan yang sama.

Data yang dikumpulkan terdiri dari data primer dan data sekunder. Data primer diperoleh dengan mendatangi dan melakukan wawancara terhadap responden dengan berpedoman pada kuesioner yang kemudian diklarifikasi dengan wawancara mendalam dengan responden terpilih. Data yang diperoleh, diolah dan analisis secara kuantitatif. Analisis kuantitatif dengan menggunakan statistik, meliputi: analisis statistik deskriptif untuk mendeskripsikan kondisi peubah serta analisis korelasi untuk menguji hipotesis yang dirumuskan. Pengujian hipotesis dengan menggunakan analisis Uji Korelasi Rank Spearman dan untuk memudahkan pengolahan data digunakan program statistik. Data kualitatif digunakan untuk memberikan penjelasan terhadap data kuantitatif.

\section{Hasil dan Pembahasan}

\section{Karakteristik Personal Kader KB}

Kondisi karakteristik personal kader $\mathrm{KB}$ di Kota Palembang didominasi umur 39-46 tahun, mayoritas tamatan SLTA, pengalaman rata-rata hampir tujuh tahun, tingkat motivasi kategori sedang, jarang mengikuti pelatihan, serta jarang ke luar sistem sosial (Tabel 1).

\section{Umur}

Dominasi umur kader KB adalah di atas 40 tahun, karena memang yang direkrut menjadi kader $\mathrm{KB}$ harus sudah berkeluarga dan berumur dewasa, mengingat bidang pekerjaannya adalah menghadapi dan memengaruhi orang-orang yang sudah berkeluarga. Kelompok usia tersebut masih produktif untuk mengembangkan diri dan mengembangkan program KB. Secara umum, kader KB pada usia tersebut mempunyai kemampuan beraktivitas yang cukup baik, hal ini merupakan suatu potensi dalam kegiatan penyuluhan $\mathrm{KB}$.

\section{Tingkat Pendidikan Formal}

Sebagaimana persyaratan untuk umur, yang membutuhkan tingkat kematangan; maka juga dibutuhkan latar belakang pendidikan yang menjadikan kader KB mampu melakukan tugas dengan baik. Pekerjaan sebagai kader KB membutuhkan keahlian dalam berkomunikasi, menyampaikan ide, dan mengarahkan pola pikir orang lain. Mayoritas kader KB dengan latar belakang pendidikan SLTA menjadi dasar untuk dapat melakukan hal tersebut dengan optimal.

Pendidikan formal sangat penting bagi seseorang untuk mengembangkan kapasitas dirinya, karena dengan mengenyam pendidikan formal yang lebih tinggi pengalaman belajar dan wawasan pengetahuan yang diperoleh juga akan meningkat. Berbekal pengalaman dan pengetahuan ini dapat dikembangkan sikap yang positif dan keterampilan yang lebih baik. Bagi kader KB, pengetahuan yang tinggi, sikap yang positif, dan keterampilan yang tinggi akan menjadikan dirinya lebih adaptif terhadap perubahan, mengatasimasalah dengan baik, dan mampu merencanakan pekerjaan dan mengevaluasinya secara lebih tepat. Tilaar (1997) menjelaskan bahwa fungsi pendidikan adalah proses menguak potensi individu dan cara manusia mampu mengontrol potensinya yang telah dikembangkan agar dapat bermanfaat bagi peningkatan kualitas hidupnya.

\section{Tingkat Pengalaman}

Sesuatu yang telah dialami seseorang akan ikut membentuk dan memengaruhi penghayatan terhadap stimulus sosial. Pengalaman dalam melakukan penyuluhan $\mathrm{KB}$ memiliki peranan yang sangat 
Tabel 1. Deskripsi Karakteristik Personal Kader KB di Kota Palembang

\begin{tabular}{|c|c|c|c|}
\hline No & Karakteristik Personal $\left(\mathrm{X}_{1}\right)$ & Kategori & Persen \\
\hline 1 & Umur & $\begin{array}{l}30-38 \text { tahun } \\
39-46 \text { tahun } \\
47-55 \text { tahun }\end{array}$ & $\begin{array}{l}18 \\
42 \\
40\end{array}$ \\
\hline 2 & $\begin{array}{l}\text { Tingkat Pendidikan formal } \\
\text { Tingkat Pengalaman }\end{array}$ & $\begin{array}{l}\text { Tamat SD } \\
\text { Tamat SLTP } \\
\text { Tamat SLTA } \\
\text { Diploma } \\
\text { Sarjana } \\
1 \text { - } 5 \text { tahun } \\
6-10 \text { tahun } \\
>10 \text { tahun }\end{array}$ & $\begin{array}{r}3 \\
8 \\
83 \\
5 \\
1 \\
39 \\
50 \\
11\end{array}$ \\
\hline 4 & Tingkat Motivasi & $\begin{array}{l}\text { Rendah } \\
\text { Sedang } \\
\text { Tinggi }\end{array}$ & $\begin{array}{r}9 \\
88 \\
3\end{array}$ \\
\hline 5 & Pelatihan yang Diikuti & $\begin{array}{l}\text { Rendah } \\
\text { Sedang } \\
\text { Tinggi }\end{array}$ & $\begin{array}{l}53 \\
32 \\
15\end{array}$ \\
\hline 6 & Tingkat Kekosmopolitan & $\begin{array}{l}\text { Rendah } \\
\text { Sedang } \\
\text { Tinggi }\end{array}$ & $\begin{array}{r}63 \\
29 \\
8\end{array}$ \\
\hline
\end{tabular}

penting bagi kader dalam mengembangkan kegiatan penyuluhan sehingga mampu menerapkan metode dan teknik penyuluhan yang tepat.

Sebagian besar kader KB memiliki pengalaman pada tingkat sedang (6-10 tahun), dengan variasi antara 1 hingga 15 tahun. Kader KB menjalankan aktivitas penyuluhan $\mathrm{KB}$ sebagai kerja sampingan. Pada tahap awal, kader KB yang baru direkrut, melakukan penyuluhan dengan didampingi oleh penyuluh $\mathrm{KB}$ atau kader senior. Melalui proses tersebut, kader KB mendapatkan pengalaman tentang pengetahuan/ materi dan keterampilan perihal metode serta teknik penyuluhan.

Pengalaman kerja yang dimiliki oleh seorang kader KB dapat berhubungan dengan kemampuan dalam menjalankan aktivitasnya, karena selama masa menggeluti pekerjaannya orang tersebut akan mengalami proses belajar termasuk memperoleh pelajaran cara mengatasi permasalahan yang dihadapi. Havelock (1969) menyatakan, pengalaman seseorang memengaruhi kecenderungannya untuk memerlukan dan siap menerima pengetahuan baru.

Sebagaimana kegiatan penyuluhan pada umumnya, kegiatan penyuluhan KB menjadikan masyarakat sebagai subjek sasaran. Kondisi sosial dan budaya masyarakat dengan latar belakang yang beraneka ragam, menghendaki kader $\mathrm{KB}$ yang memiliki kapasitas dalam menghadapi hal tersebut. van den Ban dan Hawkins (1999) menyebutkan bahwa seseorang yang melakukan penyuluhan harus memperhatikan nilai dan norma yang berlaku dalam masyarakat kliennya.

Tiga puluh dua persen kader KB merupakan tokoh masyarakat. Pengalaman sebagai tokoh masyarakat, menangani kegiatan kemasyarakatan dan mengkoordinir masyarakat ikut membantu dalam kelancaran pelaksanaan penyuluhan KB. Hal ini dapat menjadi faktor pendukung dalam pengembangan kapasitas kader KB.

\section{Tingkat Motivasi}

Motivasi kader KB di Kota Palembang pada tingkat sedang. Kebutuhan untuk bersosialisasi dengan masyarakat dan menambah pergaulan merupakan alasan terbesar yang mendasari responden menjadi 
kader KB, artinya ada tujuan yang akan dicapai yang memberi dorongan lebih untuk menjadi kader. Hal ini sejalan dengan pendapat McClelland (Barbutto et al., 2004) dan Bird (1989), bahwa motivasi terkait dengan kebutuhan seseorang. Seseorang memiliki motif atau dorongan menjadi kader KB karena ada kebutuhan yang harus dipenuhi. Dorongan tersebut bisa disebabkan adanya faktor dari luar kader KB maupun faktor internal atau keyakinan dan kepuasan internalnya; artinya ada tujuan yang akan dicapai yang memberi dorongan lebih kepada kader untuk melakukan kegiatan penyuluhan.

Sejumlah besar $(92 \%)$ responden menjadi kader KB, karena diminta oleh penyuluh KB. Seleksi pemilihan kader dilakukan secara informal, berdasarkan rekomendasi aparat kelurahan. Kader $\mathrm{KB}$ yang dipilih, biasanya anggota masyarakat yang juga aktif dalam kegiatan-kegiatan kemasyarakatan, sehingga 42\% kader KB juga berperan sebagai kader Posyandu.

Semua kader menyebutkan bahwa bertambahnya jumlah akseptor KB menjadi faktor motivasi untuk melakukan kegiatan penyuluhan dengan lebih efektif. Motivasi merupakan modal yang sangat penting bagi kader KB untuk menunjang kesuksesan dalam kegiatan penyuluhan. Motivasi yang tinggi diperlukan untuk mendorong kader dalam menyukseskan program $\mathrm{KB}$; menerima atau mengadopsi teknik serta metode penyuluhan yang baru guna efektivitas dan efisiensi kegiatan penyuluhan.

\section{Pelatihan yang Diikuti}

Pelatihan yang diikuti mayoritas kader KB (53\%) di Kota Palembang pada kategori rendah. Rendahnya pelatihan yang diikuti terkait dengan penyelenggaraan penyuluhan yang tidak secara rutin dilakukan. Pelaksanaan pelatihan merupakan tanggung jawab Kantor BKKBN Kota Palembang, sehingga tergantung alokasi anggaran yang tersedia. Penentuan peserta dari setiap kecamatan, yang akan mengikuti pelatihan dipilih berdasarkan senioritas serta hubungan kedekatan dengan penyuluh KB; sehingga terjadi kecenderungan kader yang sama mendapatkan pelatihan lebih sering sedangkan beberapa kader yang lain jarang mengikuti pelatihan. Kondisi ini menyebabkan kurangnya regenerasi, karena kader KB yang lebih senior semakin sering mengikuti pelatihan dan sebaliknya kader KB yang baru justru jarang mengikuti pelatihan.
Jenis pelatihan yang pernah diikuti adalah pelatihan organisasi dan ketatalaksanaan badan KB, pengetahuan kontrasepsi reproduksi sehat, delapan fungsi keluarga, pengertian peran dan tugas pokok, lima pola pembinaan kader, pendataan keluarga, praktek kegiatan pencatatan dan pelaporan. Sebagian besar (53\%) kader KB menyebutkan bahwa materi pelatihan belum memberikan pencerahan tentang teknik dan metode penyuluhan yang ideal. Materi pelatihan lebih banyak pada aspek yang tidak berhubungan dengan cara menghadapi (memengaruhi) masyarakat yang beraneka latar belakang sosial budaya. Implikasi dari hal ini, menjadikan pelatihan belum memberikan manfaat yang besar, menurut sebagian besar kader KB. Pelatihan kader KB diharapkan dapat memberikan kontribusi yang maksimal dalam melaksanakan programpenyuluhan KB.Maalouf(1993)menyebutkan bahwa pelatihan adalah proses pendidikan yang memerlukan lebih dari informasi yang memberi atau pengembangan keterampilan.

\section{Tingkat Kekosmopolitan}

Tingkat kekosmopolitan mayoritas kader KB (63\%) di Kota Palembang pada kategori rendah. Kader KB melakukan kunjungan ke luar sistem sosial jika ada urusan keluarga, rekreasi dengan keluarga ataupun untuk tujuan silaturrahmi dengan keluarga di luar kota.

Adanya hubungan dengan luar sistem sosial, membuka kesempatan untuk berhubungan dengan orang lain dan sumber informasi sehingga menambah wawasan baru. Slamet (2003) menyatakan bahwa dengan mengadakan hubungan dengan dunia luar membuka peluang untuk mendapatkan informasiinformasi baru ataupun pengenalan terhadap suatu inovasi baru.

\section{Faktor Eksternal Kader KB}

Sama halnya dengan kondisi karakteristik personal kader $\mathrm{KB}$, kondisi faktor eksternal yang mendukung aktivitas kader KB juga tidak optimal, baik dari dukungan keluarga, dukungan tokoh masyarakat, dukungan informasi, maupun dukungan kebijakan pemerintah daerah; namun dukungan penyuluh cukup baik (Tabel 2).

\section{Dukungan Keluarga}

Bantuan dan dorongan keluarga terhadap kader 
Jurnal Penyuluhan, September 2016 Vol. 12 No. 2

Tabel 2. Deskripsi Faktor Eksternal Kader KB di Kota Palembang

\begin{tabular}{|c|c|c|c|}
\hline No & Faktor Eksternal $\left(\mathbf{X}_{2}\right)$ & Kategori & Persen \\
\hline 1 & Dukungan Keluarga & $\begin{array}{l}\text { Rendah } \\
\text { Sedang } \\
\text { Tinggi }\end{array}$ & $\begin{array}{r}90 \\
6 \\
4\end{array}$ \\
\hline 2 & Dukungan Penyuluh KB & $\begin{array}{l}\text { Rendah } \\
\text { Sedang } \\
\text { Tinggi }\end{array}$ & $\begin{array}{l}10 \\
59 \\
31\end{array}$ \\
\hline 3 & Dukungan Tokoh Masyarakat & $\begin{array}{l}\text { Rendah } \\
\text { Sedang } \\
\text { Tinggi }\end{array}$ & $\begin{array}{r}73 \\
4 \\
23\end{array}$ \\
\hline 4 & Dukungan Informasi & $\begin{array}{l}\text { Rendah } \\
\text { Sedang } \\
\text { Tinggi }\end{array}$ & $\begin{array}{l}74 \\
13 \\
13\end{array}$ \\
\hline 5 & Dukungan Kebijakan Pemerintah Daerah & $\begin{array}{l}\text { Rendah } \\
\text { Sedang } \\
\text { Tinggi }\end{array}$ & $\begin{array}{r}68 \\
28 \\
4\end{array}$ \\
\hline
\end{tabular}

KB di Kota Palembang belum optimal. Semua keluarga kader KB setuju atas profesi anggota keluarganya sebagai sebagai kader $\mathrm{KB}$, namun sejumlah besar (90 \%) keluarga kader KB tidak membantu ketika ada masalah dalam kegiatan penyuluhan program $\mathrm{KB}$ serta tidak mendorong kader $\mathrm{KB}$ untuk mencari cara-cara baru dalam menyukseskan program KB yaitu peningkatan jumlah akseptor KB. Hal ini karena memang keluarga mayoritas para kader $\mathrm{KB}$ bukan berlatar belakang atau punya keahlian di bidang $\mathrm{KB}$.

Dukungan keluarga terhadap kader $\mathrm{KB}$ ikut menentukan perilaku dan sikap dalam profesi. Puspitawati (2012) menyebutkan bahwa motivasi untuk maju dan suka bekerja keras, hidup yang disiplin, dan kemauan untuk belajar tidak muncul begitu saja. Semua perilaku itu berada dalam suatu proses yang bermula dari kehidupan keluarga. Menurut Ramdhani dan Sumardjo (2006), dukungan keluarga merupakan salah satu faktor penting keberhasilan profesi anggota keluarga.

\section{Dukungan Penyuluh KB}

Setiap kelurahan rata-rata terdapat satu orang penyuluh dan setiap Rukun Tetangga (RT) rata-rata terdapat satu orang kader KB. Dukungan penyuluh terhadap mayoritas kader KB (59 \%) di Kota Palembang pada kategori sedang. Melalui interaksi dengan penyuluh, kader $\mathrm{KB}$ memperoleh pengetahuan/materi dan wawasan tentang program $\mathrm{KB}$; serta cara/teknik dan metode penyuluhan sehingga dapat diterapkan dalam kegiatan penyuluhan KB. Penyuluh merupakan pihak yang sering dihubungi dan dimintakan bantuan oleh kader KB, jika mengalami kesulitan serta masalah dalam kegiatan penyuluhan KB. Namun penyuluh kurang optimal mendorong kader KB untuk mencari cara-cara baru (inovasi) dalam mengupayakan penambahan jumlah akseptor $\mathrm{KB}$ serta belum optimal mendorong kader KB untuk mencari informasi dari berbagai sumber informasi tentang program penyuluhan $\mathrm{KB}$.

Penyuluh belum mengadakan pertemuan secara intens dengan kader KB. Pertemuan dibuat hanya sekali dalam tiga bulan. Agenda pertemuan diantaranya adalah untuk mengevaluasi kegiatan penyuluhan yang sudah dilakukan dan membahas rencana kegiatan yang akan dilakukan. Rendahnya tingkat pertemuan rutin antara penyuluh dan kader $\mathrm{KB}$, menyiratkan kurangnya evaluasi program serta rendahnya koordinasi kerja penyuluhan $\mathrm{KB}$ di Kota Palembang. Melalui pertemuan yang intens, diharapkan rencana dan evaluasi kerja dapat dibahas secara optimal serta kontiniu; sehingga diperlukan intensitas pertemuan yang cukup. Kartasapoetra (1987) menyatakan bahwa hubungan yang kontinu antara penyuluh dengan subjek mitra dapat menciptakan 
rasa kekeluargaan yang akan mempermudah dan mempelancar pemberian dan penerimaan informasi dalam rangka peningkatan kemampuan. Penelitian Iskandar et al., (2013) menemukan bahwa peran penyuluh sangat penting dalam mengembangkan kemampuan mitra penyuluh.

\section{Dukungan Tokoh Masyarakat}

Bantuan aparat kelurahan/RT/RW dalam menyelesaikan masalah kegiatan penyuluhan $\mathrm{KB}$, masih rendah. Pada sisi lain, memang kader KB kurang melibatkan aparat kelurahan/RT/RW untuk membantu menyelesaikan masalah, misal penyelesaian masalah penolakan calon akseptor untuk mengikuti program KB. Kader KB beralasan, bahwa melibatkan aparat kelurahan/RT/RW membutuhkan dana dan tidak ada alokasi anggaran untuk hal tersebut.

Aparat kelurahan/RT/RW tidak membantu kader KB dalam menemukan cara-cara baru dalam menambahkan jumlah akseptor KB. Kader KB juga tidak mengkonsultasikan kepada aparat kelurahan/ RT/RW tentang teknik-teknik yang mungkin dapat dilakukan dalam penyuluhan KB. Keterlibatan aparat kelurahan terbatas pada koordinasi jika ada kegiatan penyuluhan secara massal yang melibatkan tenaga penyuluh dari Dinas Kota atau Provinsi.

Tokoh agama jarang dilibatkan dalam kegiatan penyuluhan KB di Kota Palembang. Keterlibatan tokoh agama sebatas pada kegiatan penyuluhan massal yang dilakukan secara insidental. Pada kegiatan tersebut, tokoh agama diminta untuk memberikan penjelasan keabsahan program KB dari segi agama.

Tokoh masyarakat merupakan orang yang mampu memengaruhi pendapat (opini) dan memengaruhi perilaku masyarakat. Semestinya para tokoh dilibatkan secara aktif dalam kegiatan penyuluhan $\mathrm{KB}$; karena para tokohmasyarakatmerupakanjembatan masuknya suatu inovasi ke dalam masyarakat. Rogers dan Shoemaker (1987) menyebutkan tokoh masyarakat sebagai pemimpin opini (opinion leaders) dan para pemimpin opini memegang peranan penting dalam kegiatan penyuluhan terutama dalam proses adopsidifusi inovasi.

\section{Dukungan Informasi}

Ketersediaan informasi bagi kader KB di Kota Palembang masih rendah. Tingkat penguasaan yang rendah terhadap internet, menyebabkan kurangnya akses kader KB terhadap website tentang program KB. Pernah dilakukan pelatihan tentang internet, namun belum menjadikan sejumlah besar kader KB terampil mengakses internet. Akses kader KB ke Kantor Dinas Kota dan Provinsi juga terbatas, sehingga informasi yang didapatkan kader KB dari instansi tersebut juga terbatas. Pada umumnya, kader KB mendapatkan informasi (materi) tentang $\mathrm{KB}$ melalui penyuluh dan sedikit akses melalui buku pedoman/panduan KB, karena keterbatasan jumlah buku panduan.

Tingkat kesesuaian informasi dengan kebutuhan kader KB, pada kategori rendah. Kader $\mathrm{KB}$ menyebutkan bahwa website tentang program $\mathrm{KB}$ jarang di-update, sehingga informasi yang disajikan tidak mutakhir. Kader KB membutuhkan informasi yang berkaitan dengan pengetahuan dan keterampilan dalam memengaruhi seluruh lapisan masyarakat supaya ikut program KB dan hal tersebut sangat sedikit didapatkan melalui sumber informasi media cetak, elektronik, maupun dari instansi KB.

Hasil wawancara juga menunjukkan bahwa kader KB kurang termotivasi untuk mengakses lebih banyak informasi melalui berbagai media. Kader KB, jika terlibat aktif dalam mengakses sumber informasi maka akan membuka peluang terhadap penambahan wawasan sehingga meningkatkan kapasitas, sebagaimana Slamet (2003) menjelaskan bahwa tingkat keseringan mengakses sumber informasi akan memengaruhi kemampuan penyuluh.

\section{Dukungan Kebijakan Pemerintah Daerah}

Dukungan kebijakan pemerintah daerah terhadap kader KB di Kota Palembang termasuk kategori rendah. Insentif yang diberikan kepada kader KB tidak bersifat bulanan tetapi hanya diberikan per kegiatan, jika ada kegiatan yang diselenggarakan dan melibatkan kader KB. Penghargaan terhadap capaian kinerja kader KB juga belum menjadi kebijakan yang tetap dan masih bersifat insidentil.

\section{Kapasitas Kader KB di Kota Palembang}

Kapasitas kader KB sangat diperlukan untuk menyukseskan pelaksanaan program-program $\mathrm{KB}$; namun kapasitas kader KB di Kota Palembang masih rendah, baik dalam menjalankan fungsi-fungsi, memecahkan masalah, dan merencanakan kegiatan 
(Tabel 3).

\section{Kemampuan Menjalankan Fungsi-Fungsi}

Kapasitas kader KB yang rendah dalam menjalankan fungsi-fungsi, berarti bahwa kader $\mathrm{KB}$ kurang menguasai teknis pekerjaan yang tepat sesuai kaidah efisiensi dan efektifitas dan kurang menguasai aspek manajerial pekerjaan. Tingkat kapasitas kader KB yang rendah dalam menjalankan fungsi-fungsi, disumbang dari rendahnya kemampuan membentuk kelompok kerja, mengevaluasi kegiatan, melakukan pendataan, serta merumuskan target kerja.

Kader KB mengalami kesulitan memberikan informasi serta menjelaskan secara detail tentang program KB kepada calon akseptor, terutama yang berhubungan dengan masalah kesehatan akibat ikut program KB. Namun informasi yang bersifat umum, seperti tentang manfaat ikut $\mathrm{KB}$, kader $\mathrm{KB}$ cukup mampu memberikan informasi kepada calon akseptor KB. Kader KB juga bisa menjaga dengan baik rahasia/ informasi pribadi dari akseptor.

Kader KB belum mampu membentuk kelompok kerja $\mathrm{KB}$ dan tidak melakukan pendataan pada kegiatan penyuluhan $\mathrm{KB}$ sehingga program penyuluhan yang dilakukan tidak didasarkan kepada data yang valid. Data yang tersedia hanya pendataan dari kegiatan Posyandu dan pendataan keluarga yang dilakukan per lima tahun. Kader KB umumnya belum mampu mandiri untuk melaksanakan kegiatan, pada umumnya kegiatan-kegiatan dirancang oleh penyuluh dan kader KB hanya sebagai peserta. Temuan ini sejalan dengan penelitian Herartri (2008) yang menyebutkan bahwa kader $\mathrm{KB}$ belum mampu melaksanakan tugas dan fungsinya secara optimal dan masih sebatas melaksanakan yang diperintahkan oleh PKB.

\section{Kemampuan dalam Memecahkan Masalah}

Kapasitas kader KB yang rendah dalam memecahkan masalah, menunjukkan daya analisis terhadap penyebab atau sumber masalah terbatas dan kemampuannya memecahkan masalah tersebut juga lemah. Kader KB kurang mampu memecahkan masalah yang terjadi dalam kegiatan penyuluhan program $\mathrm{KB}$ dan cenderung pasif jika terjadi masalah. Umumnya kader KB, jika ada masalah, belum punya inisiatif dan inovasi dalam menyelesaikan masalah yang terjadi. Tindakan yang paling mungkin dilakukan oleh kader KB adalah meminta bantuan pihak lain (penyuluh, bidan, dokter) untuk menyelesaikan masalah.

Kadang-kadang masih ditemui, penolakan calon akseptor tidak mau ikut program KB karena faktor agama/keyakinan; jika menemui keadaan seperti ini, 68 \% kader KB menyebutkan tidak lagi mengajak calon akseptor tersebut untuk ikut program KB. Kader $\mathrm{KB}$ beralasan, bahwa hal tersebut termasuk ranah sensitif. Delapan puluh persen kader KB, jika menemui masalah yang berhubungan dengan kesehatan bagi akseptor KB, menyarankan akseptor tersebut untuk sementara waktu berhenti ikut program KB. Kader KB belum punya kemampuan untuk memberikan solusi yang lebih baik. Sebagian besar (83\%) kader KB juga kesulitan jika calon akseptor menolak ikut program

Tabel 3. Kapasitas Kader KB di Kota Palembang

\begin{tabular}{llcc}
\hline \multicolumn{1}{c}{ Indikator } & Kategori & Jumlah (orang) & Persentase (\%) \\
\hline \multirow{2}{*}{ Kemampuan menjalankan } & Rendah & 82 & 82 \\
fungsi-fungsi & Sedang & 10 & 10 \\
& Tinggi & 8 & 8 \\
Kemampuan memecahkan & Rendah & 83 & 83 \\
masalah & Sedang & 12 & 12 \\
& Tinggi & 5 & 5 \\
Kemampuan merencanakan & Rendah & 90 & 90 \\
kegiatan & Sedang & 2 & 2 \\
& Tinggi & 8 & 8 \\
Total Tingkat Kapasitas & Rendah & 82 & 82 \\
& Sedang & 10 & 10 \\
\hline
\end{tabular}


KB karena dilarang suami. Menurut kader KB, tidak ada forum pertemuan yang dilaksanakan untuk para suami dalam rangka mengajak pasangan usia subur ikut program KB. Beberapa lokasi rumah pasangan usia subur berada jauh dan sulit dijangkau dengan kendaraan bermotor. Sembilan puluh persen kader KB menyebutkan bahwa keadaan seperti tersebut tidak punya solusi atau memilih tidak melakukan tindakan apa pun. Kader KB beralasan bahwa tidak ada dana khusus untuk menjangkau daerah/kawasan yang sulit dijangkau.

Kegiatan penyuluhan KB menjadikan masyarakat sebagai subjek penyuluhan, yang memiliki berbagai latar belakang pendidikan, sosial, ekonomi, dan budaya. Terkadang tidak mudah masyarakat langsung menerimaperubahan/inovasiyang ditawarkan oleh kader KB. Diperlukan kemampuan kader KB dalam mengidentifikasi setiap masalah dalam kegiatan penyuluhan program KB, menemukan penyebab masalah, dan merumuskan solusi pemecahan masalah. Menurut Morgan (2006) kemampuan mencari jawaban atas mengapa dan bagaimana kondisi yang terjadi menentukan pencapaian tujuan yang berkelanjutan.

\section{Kemampuan dalam Merencanakan Kegiatan}

Kapasitas merencanakan kegiatan yang rendah memperlihatkan bahwa umumnya kader KB tidak melakukan perencanaan dengan cermat tentang kegiatan penyuluhan yang dilaksanakan. Kader KB tidak banyak kontribusi dalam merancang kegiatan penyuluhan KB. Kader KB tidak dilibatkan dalam menyusun jadwal kegiatan, menentukan pihak yang diundang, menentukan narasumber, serta menentukan tempat kegiatan. Semua aspek tersebut dirancang, ditentukan, dan diputuskan oleh penyuluh KB. Kader $\mathrm{KB}$ hanya menjadi pihak yang pasif, yang diikutkan dalam kegiatan yang sudah dirancang oleh penyuluh $\mathrm{KB}$.

Tingkat kapasitas kader KB di Kota Palembang termasuk kategori rendah. Tiga aspek kapasitas yang diukur yaitu melaksanakan fungsi-fungsi, kemampuan memecahkan masalah, dan kemampuan merencanakan kegiatan termasuk kategori rendah. Kader KB adalah perpanjangantanganpenyuluh dalamkegiatanpenyuluhan KB di desa. Hal ini mengindikasikan bahwa diperlukan upaya-upaya dalam mengembangkan kapasitas kader KB dalam melakukan kegiatan penyuluhan KB di Kota Palembang; karena kapasitas kader KB akan menentukan kualitas penyuluhan KB. Sebagaimana penelitian Cerf et al. (2011) menemukan bahwa kemampuan petugas penyuluh menentukan kualitas kegiatan penyuluhan.

\section{Hubungan Karakteristik Personal dan Faktor Eksternal dengan Kapasitas Kader KB}

Terdapat sebelas peubah yang digunakan dalam penelitian ini untuk melihat hubungan karakteristik personal dan faktor eksternal dengan kapasitas kader KB dalam melakukan penyuluhan di Kota Palembang.

Tabel 4. Koefisien Korelasi Karakteristik Personal dan Faktor Eksternal dengan Kapasitas Kader KB di Kota Palembang

\begin{tabular}{clc}
\hline No & \multicolumn{1}{c}{$\begin{array}{c}\text { Karakteristik personal } \\
\text { dan faktor eksternal }\end{array}$} & $\begin{array}{c}\text { Koefisien korelasi } \\
\text { (dengan kapasitas) }\end{array}$ \\
\hline 1 & Umur & 0,079 \\
2 & Tingkat Pendidikan formal & $-0,128$ \\
3 & Tingkat Pengalaman & $0,601^{* *}$ \\
4 & Tingkat Motivasi & $-0,074$ \\
5 & Pelatihan yang Diikuti & $0,640^{* *}$ \\
6 & Tingkat Kekosmopolitan & 0,080 \\
7 & Dukungan Keluarga & 0,180 \\
8 & Dukungan Penyuluh KB & $0,342^{* *}$ \\
9 & Dukungan Tokoh Masyarakat & 0,160 \\
10 & Dukungan Informasi & $0,811^{* *}$ \\
11 & Dukungan Kebijakan Pemerintah Daerah & 0,146 \\
\hline Keterangan: &
\end{tabular}


Empat peubah berhubungan nyata dengan tingkat kapasitas kader KB, yaitu: tingkat pengalaman, pelatihan yang diikuti, dukungan penyuluh $\mathrm{KB}$, dan dukungan informasi (Tabel 4). Tujuh peubah tidak berhubungan nyata dengan tingkat kapasitas kader $\mathrm{KB}$, yaitu: umur, tingkat pendidikan formal, tingkat motivasi, tingkat kekosmopolitan, dukungan keluarga, dukungan tokoh masyarakat, dan dukungan kebijakan Pemerintah Daerah.

\section{Tingkat Pengalaman}

Pengalaman sebagai seorang kader $\mathrm{KB}$ sangat menentukan tingkat kapasitas kader $\mathrm{KB}$ dalam melakukan penyuluhan $\mathrm{KB}$ di Kota Palembang. Artinya semakin lama pengalaman sebagai kader $\mathrm{KB}$ maka semakin tinggi tingkat kapasitas kader KB dalam melakukan penyuluhan program KB. Temuan ini sejalan dengan temuan Fatchiya (2010) yang menyatakan bahwa pengalaman berpengaruh terhadap kapasitas. Sumber daya yang berkualitas adalah kapasitas diri kader KB yang berkualitas sebagai faktor penting untuk menyukseskan program $\mathrm{KB}$.

Semakin lama kader KB melakukan kegiatan penyuluhan $\mathrm{KB}$, memungkinkan kader KB lebih lama mengalami proses belajar, mendapatkan lebih banyak informasi, lebih banyak mengalami tempaan dalam kegiatan penyuluhan program KB. Hal ini menjadikan kader KB lebih terampil, lebih memahami fungsinya, sehingga lebih mampu melayani kebutuhan-kebutuhan klien. Bird (1989) menyebutkan pengalaman seseorang menentukan perkembangan keterampilan, kemampuan, dan kompetensi yang penting.

\section{Pelatihan yang Diikuti}

Pelatihan yang diikuti kader $\mathrm{KB}$ sangat menentukan tingkat kapasitas kader $\mathrm{KB}$ dalam melakukan penyuluhan program KB. Artinya pelatihan punya peran yang sangat penting dalam mengembangkan kapasitas kader KB. Hal ini disebabkan pada setiap kegiatan pelatihan kader KB mendapatkan tambahan pengetahuan dan keterampilan, serta menerima informasi/inovasi mengenai kegiatan program KB. Hasil penelitian ini sejalan dengan temuan Farid (2008) yang menyatakan bahwa pelatihan terbukti secara nyata berpengaruh terhadap kapasitas sumber daya. Penelitian Marliati et al. (2008) dan Suhanda et al. (2008) menyebutkan bahwa efektivitas pelatihan bagi penyuluh merupakan faktor penting dalam mengembangkan kemampuan penyuluh dan meningkatkan hasil kerja program penyuluhan.

Kader KB sebagai perpanjangan tangan atau ujung tombak penyuluhan $\mathrm{KB}$ sangat penting untuk ditingkatkan kapasitasnya melalui kegiatan pelatihan yang sesuai dengan kebutuhan dan fungsi kader KB. Uraian di atas menunjukkan bahwa agar kapasitas kader KB dapat meningkat, dapat dilakukan dengan memberi akses kepada kader KB akan kegiatan pelatihan atau kegiatan pengembangam kemampuan yang sesuai dengan kebutuhan dan fungsi tugas kader KB.

\section{Dukungan Penyuluh KB}

Dukungan penyuluh sangatmenentukantingkat kapasitas kader $\mathrm{KB}$ dalam melakukan penyuluhan program KB. Artinya dukungan penyuluh punya peran yang sangat penting dalam mengembangkan kapasitas kader KB. Hal ini dikarenakan pada setiap pertemuan, penyuluh berupaya memberikan informasi yang berkaitan dengan kegiatan penyuluhan program $\mathrm{KB}$ dan terjadi saling tukar informasi antara kader $\mathrm{KB}$ dan penyuluh. Melalui interaksi dengan penyuluh maka kader $\mathrm{KB}$ berpeluang mengkonsultasikan permasalahan dan mendiskusikan kondisi riil di lapangan kepada penyuluh, yang pada akhirnya dapat menjadi bekal bagi kader KB dalam melakukan kegitan penyuluhan program KB. Hasil penelitian ini sejalan dengan penelitian Malta (2011) yang menyatakan bahwa interaksi dengan penyuluh memengaruhi tingkat kemampuan mitra penyuluh.

Berdasarkan hasil penelitian ini membuktikan bahwa interaksi kader KB dengan penyuluh dapat meningkatkan kapasitas kader $\mathrm{KB}$ dalam melakukan penyuluhan program $\mathrm{KB}$, maka upaya untuk meningkatkan kapasitas kader KB dapat dilakukan dengan lebih intensifnya interaksi penyuluh dengan kader KB melalui pertemuan-pertemuan yang sesuai dengan kebutuhan dan pengembangan fungsi kader KB.

\section{Dukungan Informasi}

Dukungan informasi sangat menentukan tingkat kapasitas kader KB dalam melakukan penyuluhan program KB. Artinya dukungan informasi merupakan faktor yang sangat penting diperhatikan dalam mengembangkan kapasitas kader KB. Temuan ini sejalan dengan temuan Subagio et al. 
(2008) dan Ningsih (2011) yang menyatakan bahwa keterpaparan terhadap informasi menjadikan sumber daya berkualitas. Sumberdaya yang berkualitas adalah kapasitas diri kader KB yang berkualitas sebagai faktor penting untuk menyukseskan kegiatan penyuluhan KB.

Keaktifan kader KB dalam mengakses informasi, melakukan komunikasi dan berhubungan dengan pihak-pihak luar dapat meningkatkan kapasitas kader KB dalam melakukan penyuluhan dan untuk mengatasi permasalahan yang mereka hadapi dalam kegiatan program KB sehingga menjadi lebih baik.

Akses terhadap informasi program $\mathrm{KB}$ adalah kemampuan kader $\mathrm{KB}$ untuk mengembangkan potensi diri terhadap perkembangan teknologi dan pembaharuan. Hal ini juga berkaitan dengan perkembangan proses belajar, yang menuntut kader KB untuk mencari informasi serta inovasi, baik tentang program KB maupun perihal teknik dan metode penyuluhan untuk diterapkan dalam penyuluhan $\mathrm{KB}$.

Slamet (2003) menyebutkan kemampuan seseorang dalam mencari informasi, melakukan komunikasi serta interaksi dengan pihak "pemilik" informasi menjadikan seseorang tersebut memiliki "modal" dalammembuat danmenentukan pengambilan keputusan yang terbaik. Uraian di atas menunjukkan bahwa agar kapasitas kader KB dalam kegiatan penyuluhan $\mathrm{KB}$ dapat meningkat, dapat dilakukan dengan memotivasi kader KB untuk selalu aktif mengakses informasi serta memastikan tersedianya sumber informasi yang sesuai dengan kebutuhan serta fungsi kader $\mathrm{KB}$.

\section{Peubah Tidak Berhubungan Nyata}

Umur tidak berhubungan nyata dengan kapasitas kader $\mathrm{KB}$ dalam melakukan penyuluhan. Bertambahnya umur kader KB tidak diikuti dengan kegiatan belajar yang signifikan melalui pendidikan formal maupun pendidikan nonformal tentang aspekaspek kegiatan penyuluhan KB; sehingga secara signifikan tidak terjadi peningkatan kemampuan sebagian besar kader $\mathrm{KB}$ untuk pengembangan kapasitas dalam melakukan penyuluhan KB.

Tingkat pendidikan formal tidak berhubungan nyata dengan kapasitas kader KB dalam melakukan penyuluhan. Pendidikan formal yang pernah diikuti kader $\mathrm{KB}$ adalah pendidikan formal yang tidak berhubungan langsung dengan kegiatan dalam kegiatan penyuluhan KB; sehingga tidak berhubungan langsung dengan pengembangan kapasitas kader KB. Tilaar (1997) menjelaskan bahwa proses pendidikan akan menguak potensi diri manusia. Pendidikan formal memberikan pengalaman kepada seseorang melalui proses belajar, namun pendidikan yang relevan dengan bidang pekerjaanlah yang lebih menentukan kapasitas bekerja seseorang.

Tingkat motivasi tidak berhubungan nyata dengan kapasitas kader KB dalam melakukan penyuluhan. Berdasarkan deskripsi sebelumnya menunjukkan bahwa motivasi kader KB pada kategori sedang, namun hal ini tidak diiringi dengan kesempatan untuk mendapatkan peningkatan kemampuan. Kader $\mathrm{KB}$ tidak memiliki kesempatan yang sama untuk dapat mengikuti pelatihan dalam upaya pengembangan kapasitas, peserta pelatihan dipilih berdasarkan senioritas serta hubungan kedekatan dengan penyuluh $\mathrm{KB}$.

Tingkat kekosmopolitan tidak berhubungan nyata dengan kapasitas kader KB dalam melakukan penyuluhan. Kader KB melakukan kunjungan ke luar sistem sosial jika ada urusan keluarga. Kunjungan ke luar sistem sosial yang dilakukan tidak berhubungan langsung dengan program $\mathrm{KB}$, sehingga tidak signifikan mempengaruhi kapasitas kader $\mathrm{KB}$.

Dukungan keluarga tidak berhubungan nyata dengan kapasitas kader KB dalam melakukan penyuluhan. Mayoritas keluarga kader KB tidak punya keahlian di bidang $\mathrm{KB}$, sehingga keluarga tidak membantu kader $\mathrm{KB}$ dalam mengoptimalkan tugas dan fungsi sebagai kader KB. Dukungan tokoh masyarakat tidak berhubungan nyata dengan kapasitas kader KB dalam melakukan penyuluhan. Ketiadaan anggaran, menyebabkan tokoh masyarakat kurang dilibatkan dalam kegiatan program KB; sehingga keberadaan tokoh masyarakat tidak mempengaruhi kapasitas kader KB. Dukungan kebijakan Pemerintah Daerah tidak berhubungan nyata dengan kapasitas kader KB dalam melakukan penyuluhan. Perhatian dan keberpihakan Pemerintah Daerah belum optimal terhadap program KB, sehingga kebijakan Pemerintah Daerah yang berhubungan dengan program KB belum secara signifikan meningkatkan kapasitas kader KB.

\section{Kesimpulan}

Berdasarkan hasil dan pembahasan, maka disimpulkan bahwa Kapasitas kader KB di Kota Palembang masih rendah. Kader KB belum mampu melaksanakan tugas dan fungsinya secara optimal, memecahkan masalah, serta merencanakan kegiatan. 
Kader KB masih sebatas melaksanakan yang diperintahkan oleh Penyuluh KB. Faktor yang penting diperhatikan untuk mengembangkan kapasitas kader KB di Kota Palembang adalah pelatihan yang diikuti, dukungan penyuluh, dan dukungan informasi.

\section{Daftar Pustaka}

Amanah S, Virianita R, Devina. 2009. Program KB dan Penjaminan Kesehatan Ibu dan Anak di Era Desentralisasi. Bogor: Program Studi Wanita/ PSW Pusat Studi Pembangunan Pertanian dan Pedesaan-Lembaga Penelitian dan Pengabdian kepada Masyarakat IPB.

Badan Pusat Statitik. 2013. Data Kependudukan. Jakarta (ID): BPS.

Barbutto JE., Shirley KT, Lance LB. 2004. Identifying Sources Motivation of Adult Rural Workers. Journal of Agricultural Education 45(3):11-21.

Bird BJ. 1989. Entrepreneurial Behavior. Glenview, Illinois: Scott Foresman and Company.

Cerf M, Guillot MN, Olry P. 2011. Acting as a change agent in supporting sustainable agriculture: how to cope with new professional situations? The Journal of Agricultural Education and Extension 17(1):7-19.

Farid A. 2008. Kemandirian usaha tani dalam pengambilan keputusan usahatani kasus: petani sayuran di Kabupaten Bondowoso dan Kabupaten Pasuruan. [Tesis]. Bogor (ID): Institut Pertanian Bogor.

Fatchiya A. 2010. Pola pengembangan kapasitas pembudidaya ikan kolam air tawar di Provinsi Jawa Barat.[Disertasi]. Bogor (ID): Institut Pertanian Bogor.

Harun H. 2014. Analisis Standar Pelayanan Minimum (SPM) Peserta Aktif KB (Contraceptive Prevalenci Rate/CDR) di Kecamatan Sangir Solok Selatan tahun 2012. [Tesis]. Padang (ID): Universitas Andalas Padang.

Havelock RG. 1969. Planning for Innovation Theory the Dissimination and Utilization of Knowladge. Michigan: Institute for Social Research, The University of Michigan.

Herartri R. 2008. Peran institusi masyarakat perdesaan/ perkotaan (IMP) dalam pelaksanaan program KB di era otonomi daerah. Jurnal Ilmiah KB \& KR 2(2):21-36.

Isakndar HA, Sabran M. 2013. Kajian sosiologis terhadap peran penyuluh dalam pemberdayaan masyarakat. Jurnal PMIS-UNTAN 1(3):1-24.

Kartasapoetra AG. 1987. Teknologi untuk Rakyat: Memadukan Pertumbuhan dan Pemerataan. Jakarta (ID): PT. Bina Aksara.

Maalouf WD. 1993. Planning for Effective Training: A Guide to Curriculum Development. Rome: The United Nations.

Malta. 2011. Faktor-faktor yang berhubungan dengan kinerja petani jagung di lahan gambut. Jurnal Mimbar 27(1):67-78.

Marliati, Sumardjo, Asngari PS, Tjitropranoto P, Saifuddin A. 2010. Faktor-faktor penentu peningkatan kinerja penyuluh pertanian dalam memberdayakan petani. Jurnal Penyuluhan 4(2):92-99.

Morgan P. 2006. The Concept of Capacity. Brussel: European Centre for Development Policy Management.

Ningsih K. 2011. Pengembangan sumberdaya manusia petani. Jurnal Pertanian UIM 2(1):34-45.

Puspita DR. 2011. Faktor - faktor yang memengaruhi kinerja penyuluhan keluarga berencana dan dampaknya pada kinerja kader keluarga berencana di tiga kabupaten kota di Provinsi Jawa Barat. [Disertasi]. Bogor (ID): Institut Pertanian Bogor.

Puspitawati H. 2012. Gender dan Keluarga: Konsep dan Realita di Indonesia. Bogor (ID): IPB Press.

Ramdhani M, Sumardjo. 2006. Faktor-faktor yang berhubungan dengan proses belajar dan tingkat kecakapan hidup remaja. Jurnal Penyuluhan 2(2):115-124.

Rogers EM, Shoemaker FF. 1987. Memasyarakatkan Ide-ide Baru. Hanafi A, penerjemah. Surabaya (ID): Penerbit Usaha Nasional.

Slamet M. 2003. Paradigma Baru Penyuluhan Pertanian di Era Otonomi Daerah. Di dalam: Ida Yustina dan Adjat Sudrajat, editor. Membentuk Pola Perilaku Manusia Pembangunan. Bogor (ID): IPB Press.

Subagio H, Sumardjo, Asngari PS, Tjitropranoto P, Susanto D. 2008. Kapasitas petani dalam mewujudkan keberhasilan usaha pertanian kasus petani sayuran di Kabupaten Pasuruan dan Kabupaten Malang Provinsi Jawa Timur. Jurnal Penyuluhan 4(1):11-20.

Suhanda NS, Jahi A, Sugihen BG, Susanto D. 2008. Kinerja penyuluh pertanian di Jawa Barat. Jurnal Penyuluhan 4(2):100-108.

Tilaar HAR. 1997. Pengembangan Sumber Daya Manusia dalam Era Globalisasi: Visi, Misi, dan Program Pendidikan dan Pelatihan Menuju 2020. 
Jurnal Penyuluhan, September 2016 Vol. 12 No. 2

Jakarta (ID): PT. Grasindo.

Utsman. 2002. Pengetahuan dan Perilaku Reproduksi

Sehat Wanita Usia Subur (WUS) Keluarga Pra

Sejahtera di Desa-desa Tertinggal di Kabupaten
Karanganyar Jawa Tengah. Jurnal Pemberdayaan Perempuan 2(1).

Van den Ban AW, Hawkins HS. 1999. Penyuluhan Pertanian. Yogyakarta (ID): Kanisius. 